\title{
Mid-term Comparison of Weight Loss and Nutritional Parameters After Laparoscopic Sleeve Gastrectomy and Roux-En-Y Gastric Bypass
}

\author{
Laparoskopik Sleeve Gastrektomi ve Roux-En-Y Gastrik Bypass Sonrası Kilo Verme ve \\ Beslenme Parametrelerinin Ara Dönem Karșilaștırması
}

\author{
Hasan Cantay1, Mehmet Fatih Erol'2, Haci Murat Cayci², Umut Eren Erdogdu², Evren Dilektasli², \\ Gozde Dogan², Yurdakul Deniz Firat², Nejdet Deniz Tihan², Huseyin Ayhan Kayaoglu² \\ ${ }^{1}$ Department of General Surgery, Kafkas University School of Medicine, Kars, Turkey; ${ }^{2}$ Department of General Surgery, The University \\ of Health Sciences Bursa Yuksek Ihtisas Research and Training Hospital Bursa, Turkey
}

\begin{abstract}
Aim: In treating obesity, the restrictive effects of laparoscopic sleeve gastrectomy (LSG) and malabsorptive effects of laparoscopic Roux-En-Y Gastric Bypass (LRYGB) are two distinct outcomes responsible for excess weight loss.

Material and Method: The data of 110 patients who underwent bariatric surgery for morbid obesity (Body Mass Index-BMI $\geq 40$ $\mathrm{kg} / \mathrm{m}^{2}$ ) in our hospital between 2012 and 2017 and completed the 6-month follow-up period were retrospectively evaluated. According to the surgical procedure (LSG and LRYGB), the patients were divided into two groups, with 65 patients in the LSG group and 45 in the LRYGB group. The demographic characteristics of the patients in both groups, preoperative and postoperative weight, BMI, iron, and iron-binding capacity, ferritin, vitamin B12, folic acid, hemoglobin, 25-hydroxy vitamin D, and MCV levels were compared.
\end{abstract}

Results: There was no significant difference between the groups regarding preoperative and postoperative weight or $B M I$ values and weight loss values at the 6th postoperative month ( $p>0.05$ ). While all preoperative parameters were similar between the two operation groups, a decrease in serum iron and MCV values in the LRYGB group at the 6th postoperative month was statistically significant ( $p=0.014, p=0.031$, respectively).

Conclusion: LSG and LRYGB operations can be accepted as effective surgical methods with similar mid-term results and success rates. Iron deficiency and related blood count changes can be seen more frequently in gastric bypass patients than those undergoing sleeve gastrectomy.

Key words: sleeve gastrectomy; gastric bypass; laparoscopy; bariatric surgery; weight loss; vitamin deficiency

\section{ÖZET}

Amaç: Obezite tedavisinde sleeve gastrektomide restriktif, RouxEn-Y Gastrik Bypass yönteminde ise malabsorbtif etkiler ön plandadır. Çalıșmamızda LSG ve LRYGB grubundaki hastalarımızın preoperatif ve postoperatif dönemdeki kilo ve nutrisyonel parametrelerinin karșılaștırılması amaçlanmıștır.

Materyal ve Metot: 2012-2017 yılları arasında Bursa Yüksek ihtisas Eğitim ve Araștırma Hastanesinde Genel cerrahi kliniğinde morbid obezite (Body Mass Index-BMI $\geq 40 \mathrm{~kg} / \mathrm{m}^{2}$ ) nedeniyle, bariatrik cerrahi uygulanan ve altı aylık takip dönemini tamamlayan toplam 110 hastanın verileri retrospektif olarak değerlendirildi. Hastalar uygulanan yönteme göre iki gruba ayrıldı (LSG ve LRYGB). LSG grubunda 65, LRYGB grubunda 45 hasta yer aldı. Gruplarda yer alan hastaların demografik özellikleri, preoperatif ve postoperatif dönemdeki kilo, BMI, demir ve demir bağlama kapasitesi, ferritin, vitamin B12, folik asit, hemoglobin, 25-hidroksi vitamin D ve MCV düzeyleri kaydedilip karșılaștırıld.

Bulgular: Gruplar arasında hastaların ameliyat öncesi ve sonrası kilo ve BMI değerleri ve ameliyat sonrası 6. ayda kaybedilen $\mathrm{kg}$ değerleri açısından anlamlı fark bulunamadı $(p>0,05)$. Ameliyat öncesi bütün parametreler her iki ameliyat grubu arasında benzerken, ameliyat sonrası 6. ayda LRYGB grubunda serum demir ve $M C V$ değerlerindeki düșüș istatistiksel olarak anlamlı bulundu (sırasıyla, $p=0,014, p=0,031)$.

Sonuç: Sonuç olarak, erken dönem sonuçları itibari ile LSG ve LRYGB ameliyatları benzer sonuçlara ve bașarı oranlarına sahip etkili cerrahi metodlar olarak kabul edilebilir. Bariatrik cerrahi sonrası gastrik bypass uygulanan hastalarda erken dönemde demir eksikliği ve buna bağlı semptomlar sleeve gastrektomiye göre daha sık görülebilir.

Anahtar kelimeler: sleeve gastrektomi; gastrik bypass; laparoskopi; bariatrik cerrahi; kilo kaybl; vitamin eksikliği

Iletișim/Contact: Hasan Cantay, Department of General Surgery, Kafkas University School of Medicine, Kars, Turkey • Tel: 05336235576 • E-mail: hasan_cantay@hotmail.com •Geliș/Received:06.03.2021•Kabul/Accepted:03.04.2021

ORCID: Hasan Cantay, 0000-0003-3309-8879 • Mehmet Fatih Erol, 0000-0003-0501-6223 • Hacı Murat Caycı, 0000-0002-4833-1509 • Umut Eren Erdoğdu, 0000-0001-6700-1858 • Evren Dilektaşl, 0000-0003-4357-0516 • Gözde Doğan, 0000-0003-3274-383X • Yurdakul Deniz Firat, 0000-0002-1854-4765 • Nejdet Deniz Tihan, 0000-0001-7777-0781 • Hüseyin Ayhan Kayaoğlu, 0000-0001-5807-6698 


\section{Introduction}

Obesity and its related comorbidities (such as hypertension, hyperlipidemia, and type 2 diabetes) are associated with high morbidity and mortality ${ }^{1}$. The nonsurgical treatment of morbid obesity, with diet, medical practices, and exercise, cannot achieve effective weight loss as surgery ${ }^{2,3}$. However, although effective weight loss and comorbidity resolution can be accomplished with several bariatric surgical interventions, no single method has been recognized as the gold standard ${ }^{4}$.

LSG is a widely used method, recently gaining in popularity. LSG provides an effective weight loss and comorbidity solution in obesity management with its restrictive and hormonal effects ${ }^{5,6}$. Since the pylorus and duodenum are still secure after LSG, there is a lower vitamin and nutrient deficiency rate. On the other hand, LRYGB is the optimal malabsorptive operation technique, but it is also restrictive. Vitamin and nutrient deficiency is expected during the postoperative pe$\operatorname{riod}^{7-9}$ as a decrease in the amount of food taken leads to vitamin and nutrient deficiency due to malabsorptive effects ${ }^{10-12}$.

Our study aimed to compare changes in weight and nutritional parameters of LSG and LRYGB operations in the preoperative and postoperative periods.

\section{Material and Method}

Between January 2012 and November 2017, the data of 110 patients who underwent bariatric surgery for morbid obesity (Body Mass Index-BMI $\geq 40 \mathrm{~kg}$ / $\mathrm{m}^{2}$ ) and completed a 6-month follow-up period in Bursa Yüksek Ihtisas Training and Research Hospital General Surgery Clinic were retrospectively evaluated. According to the surgery method, the patients were divided into two groups, with 65 patients in the LSG group and 45 patients in the LRYGB group. Detailed information about LSG and LRYGB techniques was given to the patients preoperatively and written informed consent was obtained. The Declaration of Helsinki carried out our study, and ethics committee approval was obtained with several 2017-15/26 from the Uludag University Faculty of Medicine Ethics Committee before the study.

The study included patients between the ages of 18-65 with a pre-op BMI $\geq 40$ and attended follow-up for six months was included in the study. Patients with a BMI of $<40$, those who underwent revision surgery, or those who did not have regular follow-up records were excluded from the study. Postoperatively, patients in both groups were enrolled in a dietician's nutritional program and prescribed multivitamin and nutrient support.

The demographic characteristics, comorbidity, preoperative and postoperative weight, body mass index (BMI), iron and iron-binding capacity, ferritin, vitamin B12, folic acid, 25-hydroxyvitamin D level, hemoglobin, and MCV (Mean Corpuscular Volume) levels were recorded and compared.

\section{Statistical Analysis}

The frequency and percentages from the descriptive criteria, the average from the location criteria, and the standard deviation from the common criteria were taken in research data analysis. Student-t-test (significance test of the difference between two means) was used to evaluate continuous data. The level of significance was taken as $\mathrm{p}<0.05$.

\section{Results}

One hundred ten patients were included in our study. Laparoscopic surgery was performed on all patients without conversion to open surgery. No incidence of mortality was recorded in our patients in the postoperative period, and there was no case of significant earlyperiod morbidity.

The age, gender, presence of comorbidity, preoperative and postoperative weight, and BMI data of the patients in the two groups were evaluated (Table 1). The LSG group was composed of $78.5 \%$ female and $21.5 \%$ male patients, with $86.7 \%$ female and $13.3 \%$ male patients in the LRYGB group. No statistical difference was observed between the groups regarding gender distribution $(p=0.266)$. The mean age of the patients in the LSG group was $38.83 \pm 10.83$, while the mean age was $37.48 \pm 10.94$ years in the LRYGB group. Again, there was no statistically significant difference between the groups regarding age distribution $(\mathrm{p}=0.526)$.

The rate of comorbidity was $41.5 \%$ in the LSG group and $51.1 \%$ in the group that underwent LRYGB, but this was not statistically significant $(\mathrm{p}=0.322)$. There was also no statistically significant difference between the groups regarding preoperative and postoperative 6th-month weight or BMI values.

Iron, iron-binding capacity, ferritin, folate, B12, $25 \mathrm{OH}$ vitamin $\mathrm{D}, \mathrm{Hgb}$, and MCV levels in both groups were evaluated in the preoperative and postoperative 6th month (Table 2). While there was no 
Table 1. Age, preoperative and postoperative weight, BMI and weight loss values of the patients

\begin{tabular}{lcccc}
\hline & & LSG & LRYGB \\
& & $(\mathrm{n}=65)$ & $35)$ & P value \\
\hline Age & & $38.83 \pm 10.83$ & $37.48 \pm 10.94$ & 0.526 \\
Weight $(\mathrm{kg})$ & Preoperative & $123.50 \pm 15.68$ & $122.46 \pm 14.83$ & 0.727 \\
& $6^{\text {th }}$ mounth & $85.07 \pm 10.67$ & $85.22 \pm 8.54$ & 0.697 \\
BMl $\left(\mathrm{kg} / \mathrm{m}^{2}\right)$ & Preoperative & $45.46 \pm 4.67$ & $45.70 \pm 5.10$ & 0.797 \\
& $6^{\text {th }}$ mounth & $31.31 \pm 3.53$ & $32.05 \pm 3.04$ & 0.254 \\
Weight loss $(\mathrm{kg})$ & $6^{\text {th }}$ mounth & $38.43 \pm 8.84$ & $36.71 \pm 10.58$ & 0.357 \\
\hline
\end{tabular}

LSG, laparoscopic sleeve gastrectomy; LRYGB, laparoscopic roux-en-y gastric bypass; BMI, body mass index, Student $\mathrm{t}$ test.

Table 2. Preoperative and postoperative iron, iron binding capacity, ferritin, folate, vitamin B12, $250 \mathrm{H}$ vitamin D, $\mathrm{Hgb}, \mathrm{MCV}$ values

\begin{tabular}{|c|c|c|c|c|}
\hline & & $\begin{array}{l}\text { LSG } \\
(n=65)\end{array}$ & $\begin{array}{l}\text { LRYGB } \\
(\mathrm{n}=45)\end{array}$ & $P$ value \\
\hline $\begin{array}{l}\text { Iron } \\
(\mu \mathrm{g} / \mathrm{dl})\end{array}$ & $\begin{array}{l}\text { Preoperative } \\
6^{\text {th }} \text { mounth }\end{array}$ & $\begin{array}{l}67.24 \pm 28.76 \\
74.09 \pm 33.53\end{array}$ & $\begin{array}{l}59.66 \pm 24.47 \\
59.38 \pm 25.00\end{array}$ & $\begin{array}{l}0.152 \\
\mathbf{0 . 0 1 4}\end{array}$ \\
\hline Iron binding capacity $(\mu \mathrm{g} / \mathrm{dl})$ & $\begin{array}{l}\text { Preoperative } \\
6^{\text {th }} \text { mounth }\end{array}$ & $\begin{array}{l}296.64 \pm 82.00 \\
260.63 \pm 76.76\end{array}$ & $\begin{array}{l}315.97 \pm 83.39 \\
277.51 \pm 86.69\end{array}$ & $\begin{array}{l}0.230 \\
0.285\end{array}$ \\
\hline $\begin{array}{l}\text { Ferritin } \\
\text { (ng/ml) }\end{array}$ & $\begin{array}{l}\text { Preoperative } \\
6^{\text {th }} \text { mounth }\end{array}$ & $\begin{array}{l}61.34 \pm 54.89 \\
56.69 \pm 48.48\end{array}$ & $\begin{array}{l}59.73 \pm 77.12 \\
46.37 \pm 59.21\end{array}$ & $\begin{array}{l}0.898 \\
0.421\end{array}$ \\
\hline $\begin{array}{l}\text { Folate } \\
\text { (ng/ml) }\end{array}$ & $\begin{array}{l}\text { Preoperative } \\
6^{\text {th }} \text { mounth }\end{array}$ & $\begin{array}{l}8.73 \pm 4.71 \\
7.44 \pm 4.08\end{array}$ & $\begin{array}{l}8.58 \pm 4.31 \\
6.97 \pm 3.38\end{array}$ & $\begin{array}{l}0.866 \\
0.527\end{array}$ \\
\hline $\begin{array}{l}\text { Vitamin B12 } \\
(\mathrm{pg} / \mathrm{ml})\end{array}$ & $\begin{array}{l}\text { Preoperative } \\
6^{\text {th }} \text { mounth }\end{array}$ & $\begin{array}{c}348.04 \pm 132.29 \\
281.64 \pm 83.38\end{array}$ & $\begin{array}{c}331.77 \pm 87.57 \\
323.73 \pm 137.62\end{array}$ & $\begin{array}{l}0.472 \\
0.071\end{array}$ \\
\hline $25 \mathrm{OH}$ vitamin $\mathrm{D}(\mathrm{ng} / \mathrm{ml})$ & $\begin{array}{l}\text { Preoperative } \\
6^{\text {th }} \text { mounth }\end{array}$ & $\begin{array}{l}25.40 \pm 14.90 \\
26.63 \pm 15.96\end{array}$ & $\begin{array}{c}20.99 \pm 9.80 \\
21.78 \pm 11.09\end{array}$ & $\begin{array}{l}0.085 \\
0.081\end{array}$ \\
\hline $\begin{array}{l}\text { Hemoglobin } \\
(\mathrm{g} / \mathrm{dl})\end{array}$ & $\begin{array}{l}\text { Preoperative } \\
6^{\text {th }} \text { mounth }\end{array}$ & $\begin{array}{l}13.62 \pm 1.62 \\
13.43 \pm 1.40\end{array}$ & $\begin{array}{l}13.29 \pm 1.37 \\
13.10 \pm 1.33\end{array}$ & $\begin{array}{l}0.270 \\
0.225\end{array}$ \\
\hline MCV & $\begin{array}{l}\text { Preoperative } \\
6^{\text {th }} \text { mounth }\end{array}$ & $\begin{array}{l}84.25 \pm 6.54 \\
84.82 \pm 6.46\end{array}$ & $\begin{array}{l}82.49 \pm 7.56 \\
81.92 \pm 7.34\end{array}$ & $\begin{array}{l}0.197 \\
\mathbf{0 . 0 3 1}\end{array}$ \\
\hline
\end{tabular}

LSG, laparoscopic sleeve gastrectomy; LRYGB, laparoscopic roux-en-y gastric bypass; MCV, mean corpuscular volume, Student t test.

statistically significant difference between the groups in the preoperative period, statistically significant decreases in serum iron and MCV values were observed in the LRYGB group at the postoperative 6th month ( $\mathrm{p}=0.014 \mathrm{p}=0.031$, respectively).

\section{Discussion}

Obesity is a multifactorial disease impacted by socioeconomic and socio-cultural influences and biological factors ${ }^{13,14}$. The most effective and sustainable results in obesity treatment are provided by bariatric surgical interventions ${ }^{15}$.

While bariatric surgical interventions are most frequently performed in women, gender does not appear to be a determinant for the method of bariatric surgery ${ }^{16,17}$. This is corroborated by our study, where most of our patients were female, and there was no statistically significant difference in gender between the LSG and LRYGB groups ( $\mathrm{p}=0.266 ; \mathrm{p}=0.526)$.

In our study, mean weight loss at the end of the sixth postoperative month was recorded as $38.43 \mathrm{~kg}$ in patients undergoing LSG and $36.71 \mathrm{~kg}$ in patients who received LRYGB. Accordingly, there was no statistically significant difference between the two groups regarding weight loss $(p=0.357)$. In other studies comparing the results of LSG with LRYGB, weight-loss rates were also found to be similar. It has been emphasized that the efficacy of LSG surgery is no less than LRYGB and that it can be an ideal surgical method ${ }^{16-18}$.

At the end of the sixth month, there was no statistically significant change in BMI between the groups: the average BMI decreased to $31.31 \mathrm{~kg} / \mathrm{m}^{2}$ in the LSG 
group and $32.05 \mathrm{~kg} / \mathrm{m}^{2}$ in the LRYGB group. This is in line with other studies that have found no significant difference in BMI change between LSG and LRYGB methods in the first six-month period ${ }^{18-21}$. In our study, similar rates for both weight loss and change in BMI were noted for both surgical methods at the end of the first six months.

Vitamin and nutrient deficiency is a common consequence of bariatric surgery due to the restriction of stomach volume or the malabsorptive nature of the procedure $^{22}$. In patients who do not receive regular multivitamin support, there may be decreases in vitamin $\mathrm{B} 12$ of $2-18 \%$ and $\mathrm{Fe}$ of $1-18 \%$, and related to this, symptoms such as fatigue, chills, and anemia may develop ${ }^{23}$. A study by Gehrer et al. conducted on 138 patients showed a significant decrease after LRYGB surgery, especially in terms of vitamin B12, during a one-year follow-up ${ }^{24}$. Although in our patients, no significant difference was found in levels of vitamin B12 between the LSG and LRGB groups during the first six months following surgery, there was a decrease in ferritin and iron levels in patients in both surgery groups at six months. However, the decrease in iron and ferritin levels was only statistically significant in the LRYGB group $(p=0.014)$. Multivitamin support is routinely given post-op; however, because of limited food intake during this period, a further possible nutrient deficiency could likely be prevented by prescribing iron preparations, particularly to patients undergoing gastric bypass surgery.

In sleeve gastrectomy surgery, a reduction in food intake is achieved by decreasing the stomach capacity ${ }^{5,6}$; in this case, no problems with food absorption are expected in the postoperative period. On the other hand, as malabsorption is an important feature of LRYGB surgery, vitamin and mineral deficiency is more likely to ensue after this procedure ${ }^{25,26}$. Additionally, removing the fundus of the stomach during sleeve gastrectomy causes a decrease in levels of ghrelin, a hormone associated with increased hunger and normally secreted from this area, causing patients to feel fewer food cravings $^{27,28}$.

After LRYGB surgery, deficiencies in vitamins and minerals such as calcium, $25(\mathrm{OH}) \mathrm{D} 3$, iron, and vitamin B12 may occur due to malabsorption ${ }^{25,26} .25$ $(\mathrm{OH})$ D3 deficiency may be seen in $14-89.7 \%$ of patients after bariatric surgery ${ }^{29}$. In our study, there was no decrease in the average $25(\mathrm{OH}) \mathrm{D} 3$ level in the postoperative period and no difference in mean 25
$(\mathrm{OH})$ D3 levels between the two groups in the preoperative or postoperative periods. The reason for this was thought to be vitamin D replacement, which was initiated in our patients in the early post-op period (1st month postoperatively).

\section{Limitations}

The relatively low number of patients in the study groups and a follow-up period of only six months, without long-term results, are limitations of our study.

Following bariatric surgery in morbidly obese patients, vitamin and nutrient deficiency may develop in the follow-up period due to restriction in food intake or malabsorption. In primarily malabsorptive interventions such as the LRYGB method, a decrease in iron and related MCV values may be more pronounced. Therefore, it is thought that an adjustment in replacement therapy during follow-up should be considered according to the surgical method used.

\section{Competing Interests}

The authors declare that they have no competing interests.

\section{References}

1. Craig MH, Margaret D, Cheryl D. Fryar CL. Ogden. Prevalence of Obesity Among Adults and Youth: United States, 20152016. National Center for Health Statistics 2017;288.

2. Kelly T, Yang W, Chen CS, Reynolds K, He J. Global burden of obesity in 2005 and projections to 2030. Int J Obes (Lond)2008;32(9):1431-7.

3. Yanovski SZ, Yanovski JA. Long-term drug treatment for obesity: a systematic and clinical review. JAMA 2014;311:7486.

4. Noah J, Smith A, Birch D, Karmali S. The Metabolic Effects of Laparoscopic Sleeve Gastrectomy: A Review. J Minim Invasive Surg Sci 2013;2(3):3-7.

5. Sarela AI, Dexter SP, O'Kane M, Menon A, McMahon MJ. Long-term follow-up after laparoscopic sleeve gastrectomy:8-9year results. Surg Obes Relat Dis 2012;8:679-84.

6. Cayci HM, Erdogdu UE, Karaman K, Budak E, Taymur İ, Buyukuysal C. Does Weight Gain During the Operation Wait Time Have an Impact on weight Loss After Laparoscopic Sleeve Gastrectomy?. Obes Surg 2017;27:338-42.

7. Karamanakos SN, Vagenas K, Kalfarentzos F, Alexandrides TK. Weight loss, appetite suppression, and changes in fasting and postprandial ghrelin and peptide-YY levels after Roux-en-Y gastric bypass and sleeve gastrectomy: A prospective, double blind study. Ann Surg 2008;247:401-7. 
8. Cottam DR, Atkinson J, Anderson A, Grace B, Fisher B. A casecontrolled matched-pair cohort study of laparoscopic Rouxen-Y gastric bypass and Lap-Band patients in a single US center with three-year follow-up. Obes Surg 2006;16:534-40.

9. Iannelli A, Anty R, Schneck AS, Tran A, Gugenheim J. Inflammation, insulin resistance, lipid disturbances, anthropometrics, and metabolic syndrome in morbidly obese patients: A case control study comparing laparoscopic RouxenY gastric bypass and laparoscopic sleeve gastrectomy. Surgery 2011;149:364-70.

10. Khwaja HA, Bonanomi G. Bariatric Surgery: Techniques, Outcome and Complications. Current Anaesthesia \& Critical Care 2010;21:31-38.

11. Barth M, Jenson C. Postoperative nursing care of gastric bypass patients. American Journal of Critical Care 2006;15(4):37888.

12. Campos GM, Rabl C, Roll GR, Peeva S, Prado K, Smith J et al. Better Weight Loss, Resolution of Diabetes, and Quality of Life for Laparoscopic Gastric Bypass vs Banding. Arch Surg 2011;146:149-55.

13. Vijgen GH, Schouten R, Bouvy ND, Greve JW. Salvage banding for failed Roux-en-Y gastric bypass. Surg Obes Relat Dis 2012;86:803-8.

14. Gilbert EW, Wolfe BM. Bariatric surgery for the management of obesity: state of the field. Plast Reconstr Surg 2012;130:94854.

15. Henkel DS, Mora-Pinzon M, Remington PL, Jolles SA, Voils CI, Gould JC et al. Trends in the prevalence of severe obesity and bariatric surgery access: a state-level analysis from 2011 to 2014. J Laparo endosc Adv Surg Tech A 2017;27(7):669-75.

16. Lee WJ, PokEH, Almulaifi A, Tsou JJ, Ser KH, Lee YC. Medium Term Results of Laparoscopic Sleeve Gastrectomy: a Matched Comparison with Gastric Bypass. Obes Surg 2015;25:1431-38.

17. Herron D, Roohipour R. Complications of Roux-en-Y gastric bypass and sleeve gastrectomy. Abdom Imaging 2012;37:7128.

18. Buchwald H, Avidor Y, Braunwald E. Bariatric surgery: a systematic review and metaanalysis. Journal of the American Medical Association 2004;292(14):1724-37.
19. Sjöström L, Lindroos A, Peltonen M, Torgerson J, Bouchard C, Carlsson B et al. Lifestyle, diabetes, and cardiovascular risk factors 10 years after bariatric surgery. The New Eng J Medicine 2004;351(26):2683-93.

20. Vidal P, Ramón JM, Goday A, Benaiges D, Trillo L, Parri A et al. Laparoscopic Gastric Bypass Versus Laparoscopic Sleeve Gastrectomy as a Definitive Surgical Procedure for Morbid. Obesity. Mid-Term Results. Obes Surg 2013;23:292-9.

21. Leyba JL, Aulestia SN, Llopis SN. Laparoscopic Roux-en-Y gastric bypass versus laparoscopic sleeve gastrectomy for the treatment of morbid obesity: a prospective study of 117 patients. Obes Surg 2011;21:212-6.

22. Parmar CD, Mahawar KK. One Anastomosis (Mini) Gastric Bypass Is Now an Established Bariatric Procedure: a Systematic Review of 12, 807 Patients. Obes Surg 2018;28(9):2956-67.

23. Miller NG, Wright BN. Mineral malnutrition following bariatric surgery. American Society for Nutrition. Adv. Nut 2013;4(5):506-17.

24. Gehrer S, Kern B, Peters T, Christoffel-Courtin C, Peterli R. Fewer nutrient deficiencies after laparoscopic sleeve gastrectomy (LSG) than after laparoscopic Roux-Y-gastric bypass (LRYGB)-a prospective study. Obes Surg 2010;20:447-53.

25. Menenakos E, Stamou K, Albanopoulos K, Papailiou J, Theodorou D, Leandros E. Laparoscopic Sleeve Gastrectomy Performed with Intent to Treat Morbid Obesity: A Prospective Single-Center Study of 261 Patients with a Median Follow-up of 1 Year. Obes Surg 2010;20:276-82.

26. Üstün BY, Köksal E. Obesity and anesthesia. Journal of Experimental and Clinical Medicine 2013;30:15-23.

27. Herron D, Roohipour R. Complications of Roux-en-Y gastric bypass and sleeve gastrectomy. Abdom Imaging 2012;37:7128.

28. Al Harakeh AB. Complications of laparoscopic Roux-en-Y gastric bypass. Surg Clin North Am 2011;91:1225-37.

29. Mierzyńska MJ, Ostrowska L, Hady HR, Dadan J. Assessment of dietary habits, nutritional status and blood biochemical parameters in patients prepared for bariatric surgery: a preliminary study. Video surgery Mini inv 2012;7(3):156-65. 